\title{
Weed management in the dry season: interferences in physiology and quality of Persian lime fruits ${ }^{1}$
}

\author{
Maria Beatriz Bernardes Soares ${ }^{2}$, Juliana Altafin Galli², \\ Monica Helena Martins ${ }^{2}$, Ana Carolina Oliveira ${ }^{2}$, Silvano Bianco ${ }^{3}$
}

\section{ABSTRACT}

Weed interference in young citrus orchards causes significant damages, especially when competition occurs during the dry season, when environmental resources are even more scarce. This study aimed to test the effects of interference periods and weed management on the physiology, yield and quality of Persian lime fruits, during the dry season. The experimental design was randomized blocks, with five treatments [hoeing; glyphosate application; decrease of stored water (March to May); critical water deficit (June to August); and water deficit throughout the dry season (March to August)] and four replications. Weed interference during the decrease of stored water and critical water deficit periods affected significantly the physiological variables, yield and total solids contents of the fruits, but to a lesser extent than for the water deficit throughout the dry season. Weed control with glyphosate resulted in 1.56 and 2.53 times more fruits per tree than hoeing and water deficit throughout the dry season, respectively. The chemical management provided better physiological and productive responses than hoeing, due to the effect of weed mulch in the water deficit season.

KEYWORDS: Citrus latifolia Tanaka, weed competition, glyphosate.

\section{INTRODUCTION}

Tahiti acid lime belongs to the Rutaceae family, Aurantioideae subfamily, Citreae tribe, Citrineae subtribe, Citrus genus and C. latifolia (Yu. Tanaka) species (Luchetti et al. 2003). It is believed that it was introduced to the Mediterranean region through Iran (Persia). Portuguese traders probably took it to Brazil, from where it was taken to Australia

\section{RESUMO}

Manejo de plantas daninhas na estação seca: interferências na fisiologia e qualidade de frutos de limão persa

A interferência de ervas daninhas em pomares cítricos jovens causa danos significativos, especialmente quando a competição ocorre durante a estação seca, quando os recursos ambientais são ainda mais escassos. Objetivou-se testar os efeitos de períodos de interferência e do manejo de plantas daninhas na fisiologia, produtividade e qualidade de frutos de limão persa, durante a estação seca. O delineamento experimental foi em blocos casualizados, com cinco tratamentos [capina com enxada; aplicação de glifosato; diminuição da água armazenada (março a maio); déficit hídrico crítico (junho a agosto); e déficit hídrico ao longo da estação seca (março a agosto)] e quatro repetições. A interferência de plantas daninhas durante o período de diminuição da água armazenada e déficit hídrico crítico afetou significativamente as variáveis fisiológicas, produtividade e teor de sólidos totais dos frutos, mas em menor grau do que o déficit hídrico ao longo da estação seca. O controle com glifosato resultou em 1,56 e 2,53 vezes mais frutos por árvore do que a capina e o déficit hídrico ao longo da estação seca, respectivamente. $\mathrm{O}$ manejo químico proporcionou melhores respostas fisiológicas e produtivas do que a capina, devido ao efeito da cobertura morta de plantas daninhas na estação de déficit hídrico.

PALAVRAS-CHAVE: Citrus latifolia Tanaka, matocompetição, glifosato.

and Tahiti, in 1824, and, from Tahiti, it arrived in the United States between 1850 and 1880 (Morton 1987).

Persian lime, known in Brazil as Tahiti acid lime, is the most often grown lime variety globally, with larger fruits, which are triploid and, therefore, seedless (Khan et al. 2017). Brazil has increased its production every year, reaching 1.481 million tons in 2018 (FAO 2020).

\footnotetext{
${ }^{1}$ Received: Feb. 19, 2021. Accepted: July 05, 2021. Published: July 23, 2021. DOI: 10.1590/1983-40632021v5167779.

${ }^{2}$ Agência Paulista de Tecnologia dos Agronegócios, Regional Centro Norte, Pindorama, SP, Brasil.

E-mail/ORCID: maria.soares@sp.gov.br/0000-0002-0772-5325; juliana.galli@sp.gov.br/0000-0002-5685-2320; mo-martinss@hotmail.com/0000-0001-8858-0609; anacarolinaoliveiraa1302@gmail.com/0000-0003-3113-7897.

${ }^{3}$ Universidade Estadual Paulista, Faculdade de Ciências Agrárias e Veterinárias, Jaboticabal, SP, Brasil. E-mail/ORCID: silvano.bianco@unesp.br/0000-0003-3025-7950.
} 
In the Brazilian citrus belt, located in the São Paulo state and southwest of Minas Gerais, the Persian lime has emerged for small citrus growers as an alternative to sweet oranges, due to its good adaptation to edaphoclimatic conditions and greater economic value (Neves et al. 2011).

Various factors may affect yield. Among them is the incorrect management of weeds (Martinelli et al. 2017). Despite the commercial importance of the Persian lime, research on crop management practices is still scarce. Thus, growers often make decisions based on superficial information for citrus or adapt the management used for sweet oranges.

In general, weed competition in citrus orchards may result in yield losses of up to $33 \%$ (Martinelli et al. 2017). The presence of weeds creates a favorable environment for pathogens that infect citrus trunks and roots, leading to yield losses. Also, weeds compete with citrus plants for growth factors, i.e., nutrients, water and light (Otieno 2020). As Singh \& Sharma (2008) reported, the most critical time to control weeds in citrus orchards is from planting to early establishment (up to 6 years), when the young citrus trees produce very little shade to suppress weeds.

In the absence of effective weed management, production losses tend to exceed those caused by other biotic factors, such as pests and pathogens (Oerke 2006), as weeds compete with cultivated plants for environmental resources (Ramesh et al. 2017). Weed management in citrus orchards involves chemical and mechanical methods. The control of these plants, lateral to the rows, avoids competition, mainly for nutrients, as this is where most of the tree roots are concentrated. The cutter, between the rows, complements the control and protects the orchard from problems with soil erosion (Durigan \& Timossi 2002).

Factors that influence the degree of interference of weeds in a crop can be related to the weed community (specific composition, density and distribution), to the crop (spacing, density, water, light, nutrients and cultivars) and to the environment (soil, climate and management practices adopted) (Pitelli \& Pitelli 2004). Weeds cause damages to the growth and production of citrus plants, directly by competing for resources such as nutrients and water during growth and releasing allelopathic substances (Blanco \& Oliveira 1978), and indirectly by acting as intermediate hosts for pests and pathogens (Chiavegato 1986, Leite Junior \& Mohan 1990).
The competition between weeds and crops doesn't happen all year round, but at a given time or period in which one of the production factors is scarce, i.e., in the dry season (Carvalho et al. 2005).

Brazilian Persian lime orchards are mostly located in small properties. Small citrus growers generally control weeds with hoeing or chemical control, both in the canopy projection area. Glyphosate is the most widely used herbicide and, in many cases, it is the unique herbicide in use. Also, it is often used with a high frequency (more than four times a year) and in high doses (greater than 2,800 $\mathrm{g} \mathrm{ha}^{-1}$ of a.i.) (Martinelli et al. 2017).

A proper weed management may reduce the unnecessary use of labor and inputs and improve crop profitability, as well as promote soil cover to create favorable conditions for a maximum production of high-quality fruits under sustainable premises for soil, water and fertility management (Bakshi et al. 2015).

The knowledge of the best control times, the most practical control methods and the weed aggressiveness potential in lime orchards may offer subsidies for an intelligent weed management. Thus, this study aimed to test the effects of interference periods and weed control methods (glyphosate or hoeing) on the physiology, yield and fruit quality of Persian lime plants, in the dry season of the Brazilian citrus belt.

\section{MATERIAL AND METHODS}

The experiment was conducted in a commercial production area of Persian lime (cultivar IAC 5 grafted on rangpur lime), in Pindorama, São Paulo state, Brazil (21.181640S; 48.892487W), in the 2018 crop season. The climate classification is Aw, according to Köppen, with an average temperature of $22.3{ }^{\circ} \mathrm{C}$ and average annual precipitation of 1,368.2 $\mathrm{mm}$ (Ciiagro 2020), with less rainfall in the winter (June to September), if compared to the summer (December to March). The monthly rainfall distribution and water balance of the study region in the experimental period are described in Figure 1.

The Persian lime orchard had 3-year-old young trees, $2.3 \mathrm{~m}$ high and a good phytosanitary aspect, spaced at 6.0 x $4.0 \mathrm{~m}$. In February 2018, the orchard received fertilization according to the results of the soil analysis and recommendations for the crop. The trees received treatments such as cleaning pruning, eradication of sick specimens, foliar fertilization 


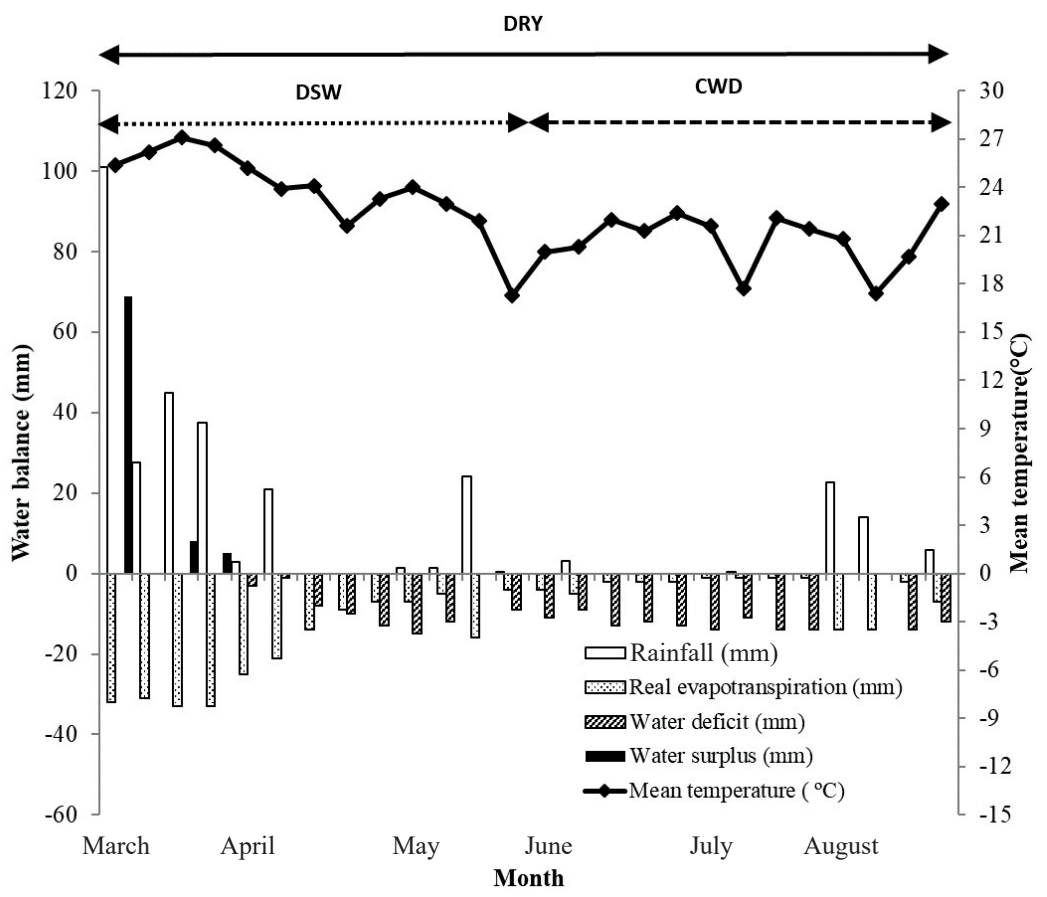

Figure 1. Weekly climatological water balance in the study region during the experimental period, in 2018 (Pindorama, São Paulo state, Brazil). Source: Ciiagro (2020). DSW: decrease in stored water; CWD: critical water deficit; DRY: water deficit throughout the dry season.

with micronutrients, mowing between rows and application of insecticides and fungicides, according to the management adopted by the producer.

The experimental design was randomized blocks, with five treatments and four replications. The treatments consisted of carrying out the weed control at pre-established times during the dry season, according to the climatological water balance of the region (Figure 1), being: a) hoeing - without coexistence between weeds and lime trees, in the canopy projection area; b) glyphosate - without coexistence with weeds, with one application of glyphosate at a dose of $1,920 \mathrm{~g} \mathrm{ha}^{-1}$ in the canopy projection area; c) decrease in stored water (DSW) - with coexistence between weeds and the crop from March to May; d) critical water deficit (CWD) - with coexistence between weeds and the crop from June to August; e) water deficit throughout the dry season (DRY) - with coexistence between weeds and the crop from March to August. Except for hoeing, the other treatments had the bush control performed with glyphosate, when applied. The experimental plots consisted of a row with 4 plants, with the 2 central ones considered as a useful plot.

The weeds were removed from the canopy projection area using hoeing up to about $1 \mathrm{~m}$ in radius from the lime tree stem. In the clean-weeded plots by chemical control, glyphosate was applied in the canopy projection area up to about $1 \mathrm{~m}$ radius from the lime tree stem, with a $\mathrm{CO}_{2}$ pressurized sprayer (tip model TXA $8002 \mathrm{VK}$ ) operated at a pressure of $3 \mathrm{kgf} \mathrm{in}^{-2}$ and spray volume of $160 \mathrm{~L} \mathrm{ha}^{-1}$. The $\mathrm{pH}$ of the spray solution was corrected to 4.0 by adding phosphonic acid. The applications took place between 07:00 and 09:00 a.m. and the wind speed did not exceed $2.5 \mathrm{~km} \mathrm{~h}^{-1}$, measured with a digital anemometer

At the end of the weed coexistence period, the weed cover (\%) and mulch (\%) were measured with the Canopeo ${ }^{\mathrm{TM}}$ software (Patrignani \& Ochsner 2015), in the canopy projection area, for the treatments $\mathrm{c}, \mathrm{d}$ and e (period of coexistence between the weeds and lime trees). The floristic survey of weeds was made in two random areas of $0.25 \mathrm{~m}^{2}$, in the crown projection area of the lime trees. The weeds were cut close to the ground, counted and identified by common, scientific and family name.

Also at the end of the coexistence period, the relative levels of total chlorophyll (SPAD index) were evaluated (Minolta chlorophyll meter, model $\mathrm{SPAD} / 502)$, as well as measurements of parameters 
related to gas exchange under saturating light. Gas exchange measurements were taken using a portable $\mathrm{CO}_{2}$ and $\mathrm{H}_{2} \mathrm{O}$ quantification system (LcPro-SD, ADC BioScientific ${ }^{\mathrm{TM}}$ Ltd.), using a constant light intensity of $1,400 \mu \mathrm{mol} \mathrm{m}^{-2} \mathrm{~s}^{-1}$ emitted by a blue-red LED light source. The leaf temperature was kept at $33.11 \pm 1.80^{\circ} \mathrm{C}$, taking measurements with the natural concentrations of $\mathrm{CO}_{2}$ in the air (between 402 and $410 \mathrm{ppm}$ ). Readings of liquid photosynthesis (A), leaf transpiration (E), substomatal $\mathrm{CO}_{2}$ concentration (Ci) and stomatal conductance (Gs) were stored and processed. With these measurements, the water-use efficiency $\left(\mathrm{A}_{\max } / \mathrm{E}\right)$ was additionally calculated. The data collection was carried out in the morning, between 09:00 and 12:30 a.m. The analyzes were performed in four replicates on the third fully expanded leaf (from the apex) of productive branches of the plants in the useful plot.

Harvests occurred with a bi-weekly or monthly frequency, accordingly to fruit availability. Only commercial-type fruits were collected (weighing more than $50 \mathrm{~g}$ ). At harvest, the fruits were counted (number of fruits per tree) and weighed (fruit weight per tree, in $\mathrm{kg}$ ). Fruit yield ( $\left.\mathrm{t} \mathrm{ha}^{-1}\right)$ was estimated by multiplying the average production per plant and the number of plants per hectare. The average fruit mass $(\mathrm{g})$ was calculated by dividing the total fruit mass by the total number of fruits harvested per tree.

For the harvest carried out in the last week of August, at the end of the experiment, 15 fruits of each treatment were randomly taken for qualitative analyzes. The experimental design of the analyzes was completely randomized, with 15 replications, being evaluated: peel thickness (mm) - thickness of the albedo and flavedo of each fruit cut in half, measured with a digital caliper (Mitutoyo ${ }^{\mathrm{TM}}$ Coolant Proof IP-67) with precision of $0.01 \mathrm{~mm}$; juice yield (JY; \%) - calculated by the relationship between the juice weight, obtained with a homemade extractor, and the fruit weight, both on a precision scale of $0.0001 \mathrm{~g}$; soluble solids (SS) - measured in ${ }^{\circ}$ Brix with a refractometer (Hanna ${ }^{\mathrm{TM}}$ HI96801), with values corrected to $20^{\circ} \mathrm{C}$, and a precision scale of $\pm 0.2 \%$; juice titratable acidity (TA) - measured by titration with $0.1 \mathrm{~N} \mathrm{NaOH}$ (IAL 2008), with results expressed as $\mathrm{g} 100 \mathrm{~g}^{-1}$ of citric acid; SS/TA ratio; and technological index (TI) - amount of soluble solids in the juice $(\mathrm{kg})$, in a $27 \mathrm{~kg}$ fruit crate, obtained by the formula: TI $=($ JY x SS x 27) $($ Di Giorgi et al. 1993).
The data were subjected to the normality test and then to analysis of variance (Anova) by the $\mathrm{F}$ test. In case of significance ( $\mathrm{p} \leq 0.05)$, the means were compared by the Tukey test, using the AgroEstat software (Barbosa \& Maldonado 2015). In addition, for a better understanding of the results, the weed cover and mulch data were correlated with the other variables evaluated by the Pearson's correlation.

\section{RESULTS AND DISCUSSION}

The most important weeds in the canopy projection area (up to $1 \mathrm{~m}$ of the tree stem) were sida weeds (Sida spp.), breadgrass (Urochloa brizantha), horseweed (Conyza spp.), tall windmill grass (Chloris polydactyla), bermuda grass (Cynodon dactylon) and, to a lesser extent, morning glory (Ipomoea spp.). The weeds showed an average density of 36 plants $\mathrm{m}^{-2}$ for DSW, 25 plants $\mathrm{m}^{-2}$ for CWD and 49 plants $\mathrm{m}^{-2}$ for DRY.

The weed interference at different times of coexistence significantly influenced all parameters evaluated (Figure 2); however, the control method (crowning by manual weeding or application of glyphosate) affected only the variables related to the gas exchange of the plants.

The correlation among photosynthetic data, weed cover and mulch is important for understanding the results, since they have opposite effects and different degrees of importance in the evaluated physiological parameters. In the treatments with competition with live weeds, either because of plants that were not adequately controlled by the glyphosate and DSW treatments or because of the coexistence in the CWD and DRY treatments, the live weed cover caused a strong positive effect on the substomatal $\mathrm{CO}_{2}$ concentration $(\mathrm{Ci})(\mathrm{r}=0.89)$ and a strong negative effect on the chlorophyll content (SPAD index) $(r=-0.72)$ and photosynthesis (A) $(\mathrm{r}=-0.84)$. For the other parameters, the correlations were negative and weak $(\mathrm{r}<-0.5)$. In the treatments that presented mulch, either due to drought (DRY and CWD) or by glyphosate to control weeds, mulch had a positive and strong correlation with the stomatal conductance parameters $(\mathrm{Gs})(\mathrm{r}=0.95)$ and transpiration $(\mathrm{E})(\mathrm{r}=0.82)$, being positive and weak for photosynthesis (A) $(\mathrm{r}=0.47)$ and chlorophyll content (SPAD index) $(r=0.44)$. The correlation was negative and moderate between mulch and wateruse efficiency (WUE) $(\mathrm{r}=-0.58)$ and negative and 


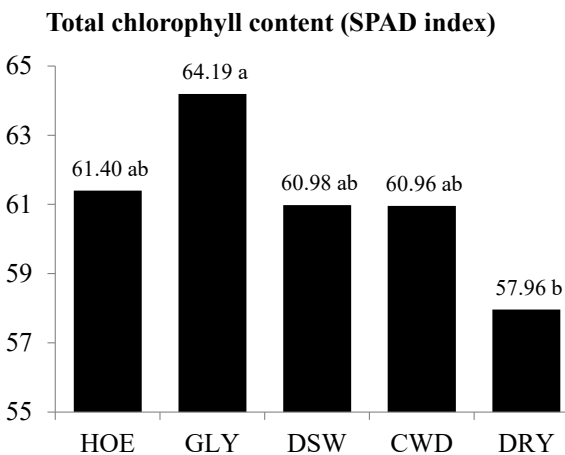

A

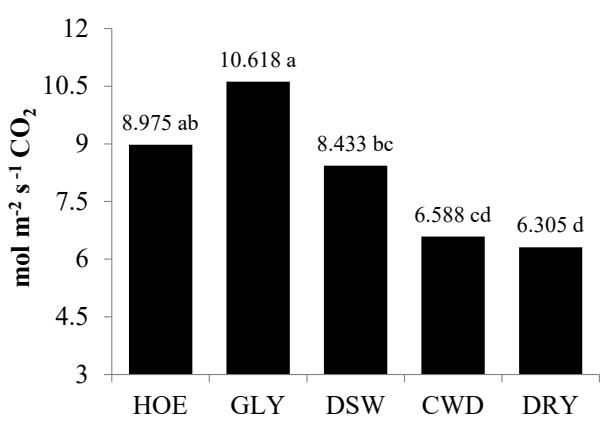

$\mathbf{E}$

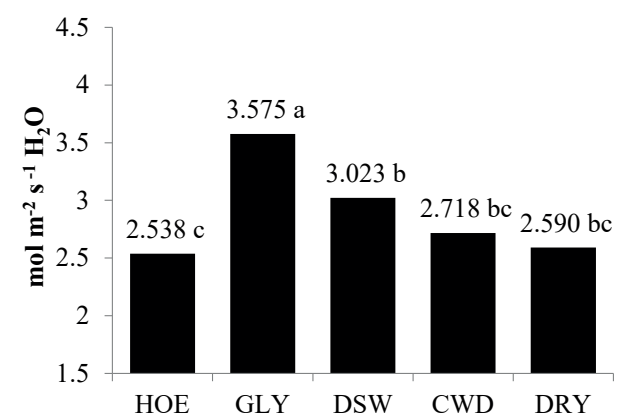

$\mathbf{C i}$

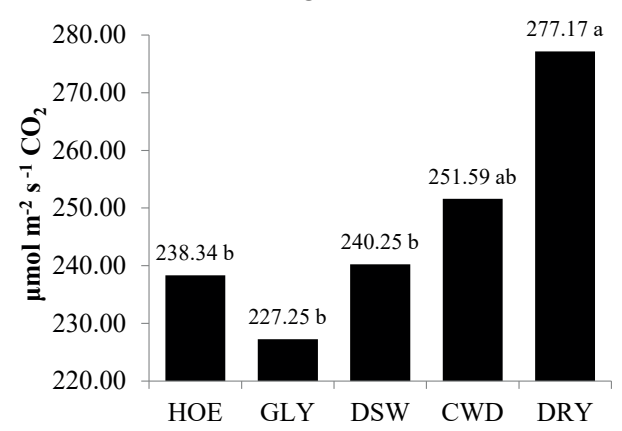

Gs

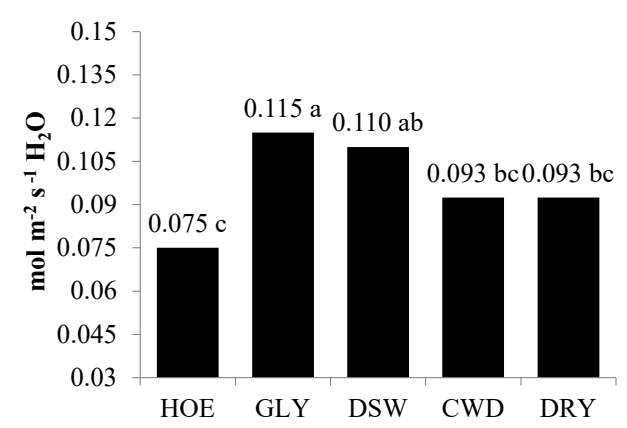

WUE

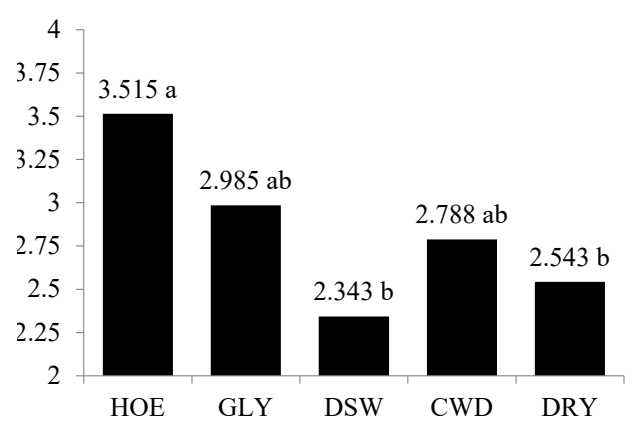

Figure 2. Total chlorophyll content (SPAD index), substomatal $\mathrm{CO}_{2}$ concentration (Ci), photosynthetic rate (A), stomatal conductance (Gs), transpiration (E) and water-use efficiency (WUE = A/E) in Persian lime trees with different coexistence times with weeds. HOE: hoeing; GLY: glyphosate; DSW: decrease in stored water (March to May); CWD: critical water deficit (June to August); DRY: water deficit throughout the dry season (March to August).

weak for the substomatal $\mathrm{CO}_{2}$ concentration $(\mathrm{Ci})$ $(\mathrm{r}=-0.44)$. Thus, the competition with live weeds affected the chlorophyll content of the plants, also affecting the efficiency of $\mathrm{CO}_{2}$ assimilation, while mulch affected more importantly water relations and water-use efficiency.

The total leaf chlorophyll (SPAD index) was higher in lime trees that did not coexist with weeds, due to their control with glyphosate, with significant differences for plants that coexisted with weeds throughout the dry season, that presented $9.7 \%$ less total leaf chlorophyll. The other treatments showed intermediate levels of chlorophyll, without significant differences $(\mathrm{p}<0.05)$.

The substomatal $\mathrm{CO}_{2}$ concentration $(\mathrm{Ci})$ was higher in the lime trees subjected to coexistence with weeds for a longer time (DRY), followed by the lime trees subjected to competition with weeds in the CWD period. The control with hoeing, glyphosate application and coexistence in the DSW period showed a lower Ci, when compared to DRY. The low $\mathrm{Ci}$ observed is generally related to the high and rapid assimilation of $\mathrm{CO}_{2}$, that is, to high photosynthetic rates. Thus, in the plots in which there was no 
coexistence with the weeds, the photosynthetic rate (A) was higher, especially in the plots treated with glyphosate $\left(10.61 \mu \mathrm{mol} \mathrm{m} \mathrm{m}^{-2} \mathrm{~s}^{-1}\right)$, even if compared to the weeding plots $\left(8.975 \mu \mathrm{mol} \mathrm{m}^{-2} \mathrm{~s}^{-1}\right)$. The treatments with lime trees subjected to coexistence with weeds for the DRY and CWD periods had the lowest photosynthetic rates, being, respectively, $40.6 \%$ and $38 \%$ lower than the control with glyphosate.

With the decrease of the water available in the soil, there is an increase in the abscisic acid (ABA) content in the leaf, inducing stomatal closure to reduce stomatal conductance $\left(\mathrm{Gs} \mathrm{H}_{2} \mathrm{O}\right)$ and water loss (Marino et al. 2017). In conditions of drought stress, there is a decrease in the conductance of $\mathrm{CO}_{2}$ across the mesophyll layer $\left(\mathrm{Gm} \mathrm{CO}_{2}\right)$ (Baker \& Rosenqvist 2004, Marino et al. 2014) due to stomatal closure, lower $\mathrm{CO}_{2}$ assimilation within the chloroplast, reducing $\mathrm{CO}_{2}$ uptake and biochemical changes in the mesophyll layer, reducing the transport of $\mathrm{CO}_{2}$ (Sorrentino et al. 2016). Similar effects were also observed in this study. The treatments where weed competition occurred in the months of lower water availability (CWD and DRY), as well as hoeing, showed lower Gs and E, with the highest values referring to the treatments that, in addition to not coexisting with weeds (glyphosate), had some vegetation cover as soil protector (DSW).

Stomatal conductance has a direct relation with water availability in the soil. It is possible that, under the conditions of this study, in the DSW period, the water content in the soil was not yet at a limiting level; therefore, the coexistence with weeds up to this period does not seem to have influenced the water content available to plants in the soil, and so in Gs. Also, a study by Bakshi et al. 2015 showed that mulch contributes to maintain the water content in the soil, an important condition in the dry period of the year.

The water-use efficiency was greater in the plots without weed competition, mainly in the hoeing treatment. In this case, high photosynthesis rates (A) were maintained, even with lower transpiration rates (E) and stomatal closure (Gs) (Figure 2). Machado et al. (2002), in a study with Valencia orange trees, found that, in July, photosynthesis is relatively less affected than stomatal opening and transpiration, due to temperature variations and vapor pressure differences. Thus, at this time of the year, the wateruse efficiency by plants is more important, because it reflects the ability to maintain the $\mathrm{CO}_{2}$ assimilation
(A) and minimize losses due to transpiration (E), despite the decrease in stomatal conductance (Gs). In the present study, the water-use efficiency of the lime trees was higher without weed competition in the plots subjected to weed control managements, especially in the hoeing treatment, reinforcing the hypothesis that competition with weeds at this time would be severely damaging.

Another factor that interferes with gas exchange is the total leaf chlorophyll content. In the studied lime trees, the SPAD index showed a higher value in the treatment without weed interference with application of glyphosate and a lower one in the plots where the lime trees lived with weeds from March to August (DRY), when the water availability of the soil was already compromised and the competition between weeds and lime trees established. Wu \& Yelenosky (1988) studied the effects of water deficit on a number of photosynthetic parameters in leaves of Valencia orange and found that the water deficit reduced the photosynthetic $\mathrm{CO}_{2}$ assimilation rate, the carboxylation reaction and the soluble protein content in leaves of citrus trees.

The present study shows how harmful it is when weeds compete with the crop for the same environment resources. In addition to all the physiological parameters evaluated, it was verified that the plants of the hoeing, CWD and DRY treatments suffered alterations in the leaves, such as curling, desiccation and abscission, probably caused by the water deficit. Leaf curling can be a defense mechanism, whereby the stomata close to avoid moisture loss in periods of water shortage. Drought promotes several defense mechanisms, like reduced growth, early leaf abscission, changes in the plant architecture and increased root length density, among others (Bosabalidis \& Kofidis 2002, Tardieu 2012).

In the hoeing treatment, both live weed cover and mulch were absent, as crowning by mechanical weeding tends to drag cut weed residues out of the canopy projection area, leaving the soil completely uncovered. Thus, despite the benefit of the total absence of competition with weeds for resources, the absence of mulch and its possible effect of reducing water availability in the more superficial layers of the soil acted as a limiting factor to the use of other resources available for the lime trees, if compared to application of glyphosate.

Physiological changes resulting from water deficit may also influence plant yield, as well as fruit 
quality. Weed interference significantly affected the number of fruits per tree and yield of the Persian lime orchard (Table 1).

The correlation among yield components, weed cover and mulch is much less pronounced than the photosynthetic data, because these parameters result from the complex interaction of various factors throughout the entire time of fruit formation, development and growth. Thus, the live weeds on the ground cover showed a negative and moderate correlation for number of fruits per tree $(r=-0.56)$, mass of fruits per tree $(r=-0.60)$ and yield $(r=-0.60)$, and a negative and negligible correlation for fruit mass $(r=-0.024)$. The presence of mulch showed a moderate negative correlation for fruit mass $(\mathrm{r}=-0.66)$, a positive and weak correlation for number of fruits per tree $(\mathrm{r}=0.36)$ and positive and negligible correlations for mass of fruits per tree $(\mathrm{r}=0.25)$ and yield $(\mathrm{r}=0.25)$.

Plants that did not suffer from weed interference due to chemical control with glyphosate or hoeing were 1.56 and 2.53 times more productive, respectively, than those that lived with weeds throughout the dry season. The DSW and CWD treatments showed an intermediate performance between the glyphosate application and DRY treatments, not differing between them. In this study, there is a link between yield and number of fruits per tree, since the average weight of the fruits was not different among the treatments, probably due to the grower's decision to harvest only the fruits considered marketable (average fruit weight greater than $50 \mathrm{~g}$ ). An effect observed in the present study (but not measured) corroborates Gonçalves et al.
(2018), who related that lime trees coexisting with weeds in periods of lower water availability reduce the amount of fruits per plant due to a greater fall of immature fruits.

When comparing the treatments without weed interference, the glyphosate application showed a higher yield and number of fruits than hoeing (Table 1). This difference may be related to the formation of a mulch layer, protecting and conserving moisture in the soil under the canopy of the lime trees. Despite the low direct correlation between mulch and main production components, the number of fruits per tree, mass of fruits per tree and yield showed a strong and positive correlation $(r>0.90)$ with photosynthesis (A), which, in turn, had a positive direct correlation with mulch $(\mathrm{r}=0.47)$ and a positive and strong correlation $(\mathrm{r}>0.70)$ with transpiration (E), an important indicator of leaf hydration, which had a positive and strong correlation with mulch $(\mathrm{r}=0.82)$. Mulch on the top of the soil surface may improve the soil moisture conditions, as a result of decreased evaporation from the soil surface; improve the soil physical conditions, including the structural stability of the topsoil; increase the soil organic matter; reduce erosion; and affect some plant nutrients (Alharbi 2017). This condition becomes decisive if considered that the orchard in this study is very young ( 3 years old), whose roots have not been established in-depth in the soil profile yet.

Not only yield is affected by competition in the dry season, but also the fruit quality. The periods of coexistence with weeds significantly influenced the peel thickness and the amount of soluble solids of the Persian lime fruits. The control methods used to

Table 1. Number and total weight of fruits per plant, yield and average fruit weight (mean \pm standard error) of Persian lime trees using different methods of weed control and periods of coexistence with weeds.

\begin{tabular}{|c|c|c|c|c|}
\hline \multirow{2}{*}{ Treatments } & \multirow{2}{*}{$\begin{array}{l}\text { Number of } \\
\text { fruits per tree }\end{array}$} & Fruit weight per tree & Yield & Fruit weight \\
\hline & & $\mathrm{kg}$ & $\mathrm{t} \mathrm{ha}^{-1}$ & $\mathrm{~g}$ \\
\hline $\mathrm{HOE}$ & $100.25 \pm 13.89 b$ & $6.28 \pm 1.31 \mathrm{~b}$ & $2.51 \pm 0.52 \mathrm{~b}$ & $62.48 \pm 6.77$ \\
\hline GLY & $156.25 \pm 10.87 \mathrm{a}$ & $8.53 \pm 0.98 \mathrm{a}$ & $3.41 \pm 0.39 \mathrm{a}$ & $55.21 \pm 6.46$ \\
\hline DSW & $77.75 \pm 7.29 \mathrm{bc}$ & $4.36 \pm 0.41 \mathrm{bc}$ & $1.74 \pm 0.17 \mathrm{bc}$ & $56.08 \pm 3.61$ \\
\hline CWD & $75.75 \pm 10.77 \mathrm{bc}$ & $4.13 \pm 0.46 \mathrm{bc}$ & $1.64 \pm 0.18 \mathrm{bc}$ & $54.54 \pm 1.06$ \\
\hline DRY & $65.00 \pm 6.48 \mathrm{c}$ & $3.95 \pm 0.87 \mathrm{c}$ & $1.58 \pm 0.35 \mathrm{c}$ & $60.38 \pm 4.96$ \\
\hline \multicolumn{5}{|l|}{$\overline{\text { Anova }}$} \\
\hline $\mathrm{F}_{\text {Treatments }}$ & $40.93 * *$ & $16.20 * *$ & $16.25 * *$ & $1.55^{\mathrm{ns}}$ \\
\hline$F_{\text {blocks }}$ & $3.94 * *$ & $0.91^{\mathrm{ns}}$ & $0.93^{\mathrm{ns}}$ & $1.44^{\mathrm{ns}}$ \\
\hline $\mathrm{CV}(\%)$ & 12.03 & 17.86 & 17.87 & 9.73 \\
\hline
\end{tabular}

Means followed by the same letter in the same column did not differ significantly. ${ }^{* *}$ Significant $(\mathrm{p}<0.01)$; ${ }^{\text {ns }}$ not significant (p $\left.>0.05\right)$. HOE: hoeing; GLY: glyphosate; DSW: decrease in stored water (March to May); CWD: critical water deficit (June to August); DRY: water deficit throughout the dry season (March to August). 
prevent weed interference (hoeing or glyphosate) did not significantly affect the quality variables (Table 2).

The fruits of the treatments that suffered weed interference in the final stage of fruit maturation (CWD and DRY) presented peel thickness of 2.34 and 2.59 , respectively, significantly greater than in the treatments without weed interference. This increase is more pronounced when the period of coexistence continues throughout the dry season. Thick peels provide high levels of oil for extraction and resistance against pests and mass loss due to dehydration, increasing the shelf life of the fruits. However, an excessively thick peel is undesirable and gives the consumer the impression of consuming immature fruits. In general, a citrus fruit with a thicker peel has less juice and is more susceptible to develop physiological disorders such as fruit splitting and creasing (Li \& Chen 2017).

As in the study by Gonçalves et al. (2018), with oranges, in the present research, the levels of soluble solids are higher in the treatments where there was a greater yield and a greater number of fruits per plant, which were the treatments in which the fruits ripened without the coexistence with weeds (Table 2). Although plants with a greater number of fruits accumulate less sugar, due to the greater competition for photoassimilates, in this case, the photosynthetic rate at the end of the water restriction period was higher in the treatments with no weeds (Figure 2). It must also be taken into account that the decrease in water availability during the ripening of Persian lime fruits leads to an increase in the internal concentration of sugars (Miranda \& Campelo Júnior 2010). However, even with differences among the treatments, none of them affected the Persian lime fruits at a level high enough to declassify them from the standard required for commercialization, which is $6.5^{\circ}$ Brix.

The parameters juice yield, titratable acidity, SS/TA ratio and technological index did not differ significantly among the treatments (Table 2). The juice yield values ranged from 0.36 to 0.42 . According to Siqueira \& Salomão (2017), the minimum content for commercialization is $40 \%(0.40)$, a value that was reached, although not statistically different, in the treatment with glyphosate. For titratable acidity, the values obtained in the study remained within the standard recommended by the Brazilian legislation, where the minimum value established is $5.0 \mathrm{mg} 100 \mathrm{~mL}^{-1}$ of citric acid (Brasil 2000). According to Siqueira \& Salomão (2017), the SS/TA ratio is not as important for acid limes and lemons as it is for oranges and tangerines, for example, because, during their maturation, the acid concentration remains high and within the classification standards for citrus of the São Paulo state (CEAGESP 2011), since there is no minimum ratio established for Tahiti acid lime.

Contrary to what producers advocate, the decision of not controlling weeds during the dry season drastically affects the yield and physiology of Persian lime plants, compromising the soluble solids content of the fruit, as well as the yield. During the dry season, when weed control is partially done, allowing the coexistence with the crop during the DSW or CWD periods, the same effects were also observed, but with a lesser intensity, if compared to the entire dry season. Among the control methods, the glyphosate application in the canopy projection area provides better results in the physiology, yield

Table 2. Peel thickness (PT), juice yield (JY), soluble solids (SS), titratable acidity (TA), SS/TA ratio and technological index (TI) (mean \pm standard error) of Persian lime fruits using different methods of weed control and periods of coexistence with weeds.

\begin{tabular}{|c|c|c|c|c|c|c|}
\hline \multirow{2}{*}{ Treatments } & PT & JY & SS & TA & \multirow{2}{*}{$\mathrm{SS} / \mathrm{TA}$} & TI \\
\hline & $\mathrm{mm}$ & $\%$ & ${ }^{\circ}$ Brix & mg100 $\mathrm{mL}^{-1}$ of citric acid & & kg SS crate ${ }^{-1}$ \\
\hline $\mathrm{HOE}$ & $1.99 \pm 0.37 \mathrm{~b}$ & $0.38 \pm 0.06$ & $10.00 \pm 0.26 \mathrm{abc}$ & $9.63 \pm 0.32$ & $1.04 \pm 0.05$ & $1.02 \pm 0.17$ \\
\hline GLY & $1.81 \pm 0.52 \mathrm{~b}$ & $0.42 \pm 0.08$ & $10.53 \pm 0.15 \mathrm{a}$ & $10.31 \pm 0.18$ & $1.02 \pm 0.03$ & $1.20 \pm 0.17$ \\
\hline DSW & $2.00 \pm 0.40 \mathrm{~b}$ & $0.39 \pm 0.05$ & $10.17 \pm 0.31 \mathrm{ab}$ & $10.04 \pm 0.43$ & $1.01 \pm 0.08$ & $1.06 \pm 0.08$ \\
\hline CWD & $2.34 \pm 0.49 \mathrm{ab}$ & $0.37 \pm 0.05$ & $9.87 \pm 0.16 \mathrm{bc}$ & $9.89 \pm 0.51$ & $0.99 \pm 0.07$ & $0.98 \pm 0.16$ \\
\hline DRY & $2.59 \pm 0.29 \mathrm{a}$ & $0.36 \pm 0.06$ & $9.47 \pm 0.15 \mathrm{c}$ & $10.26 \pm 0.24$ & $0.92 \pm 0.03$ & $0.92 \pm 0.04$ \\
\hline
\end{tabular}

Anova

\begin{tabular}{lllllll}
$\mathrm{F}$ & $4.91^{* *}$ & $1.13^{\mathrm{ns}}$ & $9.87^{* *}$ & $1.81^{\mathrm{ns}}$ & $2.21^{\mathrm{ns}}$ & $2.50^{\mathrm{ns}}$ \\
\hline $\mathrm{CV}(\%)$ & 19.77 & 10.96 & 21.59 & 3.56 & 5.45 & 11.09 \\
\hline
\end{tabular}

Means followed by the same letter in the same column did not differ significantly. ** Significant ( $p<0.01)$; ${ }^{\text {ns }}$ not significant ( $\left.p>0.05\right)$. HOE: hoeing; GLY: glyphosate; DSW: decrease in stored water (March to May); CWD: critical water deficit (June to August); DRY: water deficit throughout the dry season (March to August). 
and quality of fruits than hoeing, by allowing the weed residues to remain on the soil, protecting it from moisture loss and maintaining a high stomatal conductivity and $\mathrm{CO}_{2}$ assimilation, in addition to reducing the energy expenditure of lime trees in mechanisms of escape from water deficiency, such as winding, desiccation and leaf abscission, and preventing the fall of immature fruits.

\section{CONCLUSIONS}

1. The critical period for preventing weed interference in Persian lime orchards (young trees of 3 years) in the dry season, in the São Paulo state, is from March to August, during the dry season;

2. The weed control with glyphosate resulted in 1.56 and 2.53 times more fruits per tree than hoeing and water deficit throughout the dry season, respectively;

2. The use of chemical management provides better physiological and productive responses of the crop than hoeing, due to the effect of weed mulch, in the water deficit season.

\section{REFERENCES}

ALHARBI, A. Effect of mulch on soil properties under organic farming conditions in center of Saudi Arabia. Mechanization in Agriculture \& Conserving of the Resources, v. 63, n. 4, p. 161-167, 2017.

BAKER, N. R.; ROSENQVIST, E. Applications of chlorophyll fluorescence can improve crop production strategies: an examination of future possibilities. Journal of Experimental Botany, v. 55, n. 403, p. 1607-1621, 2004.

BAKSHI, P.; WALI, V. K.; IQBAL, M.; JASROTIA, A.; KOUR, K.; AHMED, R.; BAKSHI, M. Sustainable fruit production by soil moisture conservation with different mulches: a review. African Journal of Agricultural Research, v. 10, n. 52, p. 4718-4729, 2015.

BARBOSA, J. C.; MALDONADO JUNIOR, W. AgroEstat: sistema para análises estatísticas de ensaios agronômicos. Jaboticabal: Unesp, 2015.

BLANCO, H. G.; OLIVEIRA, D. A. Estudos dos efeitos da época de controle do mato sobre a produção de citrus e a decomposição da flora daninha. Arquivos do Instituto Biológico, v. 45, n. 1, p. 25-36, 1978.

BOSABALIDIS, A. M.; KOFIDIS, G. Comparative effects of drought stress on leaf anatomy of two olive cultivars. Plant Science, v. 163, n. 2, p. 375-379, 2002.
BRASIL. Ministério da Agricultura, Pecuária e Abastecimento. Instrução Normativa $n^{\circ} 1$, de 7 de janeiro de 2000. Aprova o regulamento técnico geral para fixação dos padrões de identidade e qualidade para polpa de fruta (e suco de fruta). 2000. Available at: http:// extranet.agricultura.gov.br/sislegisconsulta/consultarLe gislacaodo?operacao=visualizar\&id $=7777$. Access on: 15 June 2021.

CARVALHO, J. E. B.; NEVES, C. S. V. J.; MENEGUCCI, J. L. P.; SILVA, J. A. A. Práticas culturais. In: MATTOS JUNIOR, D.; DE NEGRI, J. D.; PIO, R. M.; POMPEU JUNIOR, J. (ed.). Citros. Campinas: Instituto Agronômico, 2005. p. 569-584.

CENTRO INTEGRADO DE INFORMAÇÕES AGROMETEOROLÓGICAS (Ciiagro). Balanço hídrico local. 2020. Available at: http://www.ciiagro.sp.gov. $\mathrm{br} /$ ciiagroonline/listagens/bh/lbalancohidricolocal.asp. Access on: 05 July 2020.

CHIAVEGATO, L. G. Biologia do ácaro Brevipalpus phoenicis em citros. Pesquisa Agropecuária Brasileira, v. 21, n. 8, p. 813-816, 1986.

COMPANHIA DE ENTREPOSTOS E ARMAZÉNS GERAIS DE SÃO PAULO (CEAGESP). Normas de classificação de citros de mesa: programa brasileiro para modernização da horticultura. São Paulo: CEAGESP, 2011.

DI GIORGI, F.; IDE, B. Y.; DIB, K.; MARCHI, R. J.; TRIBONI, H. R.; MARCHI, R. J.; WAGNER, R. L. Qualidade da laranja para industrialização. Laranja, v. 14, n. 1, p. 97-118, 1993.

DURIGAN, J. C.; TIMOSSI, P. C. Manejo de plantas daninhas em pomares citricos. Bebedouro: EECB, 2002.

FOOD AND AGRICULTURE ORGANIZATION OF THE UNITED NATIONS (FAO). Faostat. 2020. Available at: http://www.fao.org/faostat/. Access on: 08 June 2020.

GONÇALVES, G. S.; CARVALHO, J. E. B.; GARCIA, M. V. B.; GAMA, L. A.; AZEVEDO, C. L. L. L.; SILVA, J. F. Periods of weed interference on orange tree crops. Planta Daninha, v. 36, e0181798102018, 2018.

INSTITUTO ADOLFO LUTZ (IAL). Métodos físicoquímicos para análise de alimentos. São Paulo: Instituto Adolfo Lutz, 2008.

KHAN, M. M.; Al-YAHYAI, R.; AL-SAID, F. (ed.). The lime: botany, production and uses. Wallingford: CABI, 2017.

LEITE JUNIOR, R. P; MOHAN, S. K. Integrated management of citrus bacterial canker disease caused by Xanthomonas campestris pv. citri in the state of Paraná, Brazil. Crop Protection, v. 9, n. 1, p. 3-7, 1990.

LI, J.; CHEN, J. Citrus fruit-cracking: causes and occurrence. Horticultural Plant Journal, v. 3, n. 6, p. 255 260, 2017. 
LUCHETTI, M. A.; MATTOS JUNIOR, D.; DE NEGRI, J. D.; FIGUEREDO, J. O. Aspectos gerais e distribuição de cultivo. In: MATTOS JUNIOR, D.; DE NEGRI, J. D.; FIGUEIREDO, J. O. (ed.). Lima ácida Tahiti. Campinas: IAC, 2003, p. 1-12.

MACHADO, E. C.; MEDINA, C. L.; GOMES, M. D. M. D. A.; HABERMANN, G. Variação sazonal da fotossíntese, condutância estomática e potencial da água na folha de laranjeira 'Valência'. Scientia Agricola, v. 59, n. 1, p. 53-58, 2002.

MARINO, G.; BRUNETTI, C.; TATTINI, M.; ROMANO, A.; BIASIOLI, F.; TOGNETTI, R.; LORETO, F.; FERRINI, F.; CENTRITTO, M. Dissecting the role of isoprene and stress-related hormones (ABA and ethylene) in Populus nigra exposed to unequal root zone water stress. Tree Physiology, v. 37, n. 12, p. 1637-1647, 2017.

MARINO, G.; PALlOZZI, E.; COCOZZA, C.; TOGNETTI, R.; GIOVANNELLI, A.; CANTINI, C.; CENTRITTO, M. Assessing gas exchange, sap flow and water relations using tree canopy spectral reflectance indices in irrigated and rainfed Olea europaea L. Environmental and Experimental Botany, v. 99, n. 1, p. 43-52, 2014.

MARTINELLI, R.; MONQUERO, P. A.; FONTANETTI, A.; CONCEIÇÃO, P. M.; AZEVEDO, F. A. Ecological mowing: an option for sustainable weed management in young citrus orchards. Weed Technology, v. 31, n. 2, p. 260-268, 2017.

MIRANDA, M. N.; CAMPELO JÚNIOR, J. H. Desenvolvimento e qualidade da lima ácida Tahiti em Colorado do Oeste, RO. Revista Ceres, v. 57, n. 6, p. 787794, 2010.

MORTON, J. Tahiti lime. In: MORTON, J. F. Fruits of warm climates. Miami: J. F. Morton, 1987. p. 172-175.

NEVES, M. F.; TROMBIN, V. G.; LOPES, F. F.; KALAKI, R.; MILAN, P. Brazil's citrus belt (São Paulo and Triângulo Mineiro). In: NEVES, M. F.; TROMBIN, V. G. The orange juice business: a Brazilian perspective. Wageningen: Wageningen Academic Publishers, 2011. p. 53-57.
OERKE, E. C. Crop losses to pests. The Journal of Agricultural Science, v. 144, n. 1, p. 31-43, 2006.

OTIENO, H. M. O. Simplified orange (Citrus spp.) production guide for small-scale farmers. Asian Journal of Agricultural and Horticultural Research, v. 5, n. 1, p. 23-27, 2020.

PATRIGNANI, A.; OCHSNER, T. E. Canopeo: a powerful new tool for measuring fractional green canopy cover. Agronomy Journal, v. 107, n. 6, p. 2312-2320, 2015.

PITELli, R. A.; PITELli, R. L. C. M. Biologia e ecofisiologia das plantas daninhas. In: VARGAS, L.; ROMAN, E. S. (ed.). Manual de manejo e controle de plantas daninhas. Bento Gonçalves: Embrapa Uva e Vinho, 2004. p. 29-56.

RAMESH, K.; MATLOOB, A.; ASLAM, F.; FLORENTINE, S. K.; CHAUHAN, B. S. Weeds in a changing climate: vulnerabilities, consequences, and implications for future weed management. Frontiers in Plant Science, v. 8, e95, 2017.

SINGH, M.; SHARMA, S. D. Benefits of triazine herbicides and other weed control technology in citrus management. In: LEBARON, H. M.; MCFARLAND, J. E.; BURNSIDE, O. C. (ed.) The triazine herbicides: 50 years of revolutionizing agriculture. Amsterdan: Elsevier, 2008. p. 199-209.

SIQUEIRA, D. L.; SALOMÃO, L. C. C. Citros: do plantio à colheita. Viçosa: UFV, 2017.

SORRENTINO, G.; HAWORTH, M.; WAHBI, S.; MAHMOOD, T.; ZUOMIN, S.; CENTRITTO, M. Abscisic acid induces rapid reductions in mesophyll conductance to carbon dioxide. Plos One, v. 11, e0148554, 2016.

TARDIEU, F. Any trait or trait-related allele can confer drought tolerance: just design the right drought scenario. Journal of Experimental Botany, v. 63, n. 1, p. 25-31, 2012.

WU, J. C. V.; YELENOSKY, G. Water deficit and associated changes in some photosynthetic parameters in leaves of 'Valencia' orange (Citrus sinensis [L]. Osbeck). Plant Physiology, v. 88, n. 2, p. 375-378, 1988. 